\title{
Inclisiran for the Treatment of Cardiovascular Disease: A Short Review on the Emerging Data and Therapeutic Potential
}

This article was published in the following Dove Press journal:

Therapeutics and Clinical Risk Management

\author{
Constantine E Kosmas' \\ Alba Muñoz Estrella ${ }^{2}$ \\ Andreas Skavdis ${ }^{3}$ \\ Edilberto Peña Genao ${ }^{4}$ \\ lan Martinez ${ }^{5}$ \\ Eliscer Guzman' \\ 'Department of Medicine, Division of \\ Cardiology, Montefiore Medical Center, \\ Bronx, NY, USA; '2Department of \\ Medicine, Mount Sinai St. Luke's-West \\ Hospital, New York, NY, USA; ${ }^{3}$ School of \\ Medicine, University of Athens, Athens, \\ Greece; ${ }^{4}$ Cardiology Clinic, Cardiology \\ Unlimited, PC, New York, NY, USA; \\ ${ }^{5}$ Department of Medicine, John \\ H. Stroger, Jr. Hospital of Cook County, \\ Chicago, IL, USA
}

\begin{abstract}
Proprotein convertase subtilisin kexin 9 (PCSK-9)-targeting therapy has arisen as a new line for the treatment of hyperlipidemia. Inclisiran is a double-stranded small RNA molecule that works by blocking the transcription of PCSK-9, leading to a reduction of PCSK9 levels in the hepatocytes, resulting in an increased expression of low-density lipoprotein (LDL) receptors in the hepatocyte membrane and, as a consequence, it reduces the circulating levels of LDL cholesterol (LDL-C). Compared to the other LDL-C-lowering medications, such as statins, ezetimibe and PCSK-9 inhibitors, inclisiran proposes an infrequent dosing of twice a year, while simultaneously providing a significant reduction of LDLC. Its prolonged effect offers an advantage against medication non-compliance, which is one of the main causes for not achieving LDL-C goals with standard therapy. Inclisiran has also proven to have a relatively safe profile with adverse effects occurring in similar frequency as with placebo. This review aims to present and discuss the current clinical and scientific data pertaining to the role of inclisiran in the management of hypercholesterolemia and treatment of cardiovascular disease (CVD).
\end{abstract}

Keywords: proprotein convertase subtilisin kexin 9, PCSK-9, inclisiran, hypercholesterolemia, cardiovascular disease, CVD

\section{Introduction}

Cardiovascular disease (CVD) represents the leading cause of death worldwide. ${ }^{1}$ Lipid-lowering therapy is one of the mainstay therapies for cardiovascular risk reduction. Clinical studies have shown a proportional relationship between reduction of lowdensity lipoprotein cholesterol (LDL-C) and reduction of cardiovascular risk. ${ }^{2}$ Per guidelines, ${ }^{3,4}$ statins represent the first line of treatment for LDL-C lowering, with second-line medications including ezetimibe and PCSK9 inhibitors. Failure to achieve optimal levels of LDL-C may be of multifactorial etiology; however, in the majority of the cases, it has been related to low adherence. ${ }^{5-7}$ Factors leading to low adherence may include dosing frequency, number and cost of the medications and intolerability to adverse effects. ${ }^{5,6}$ Statins and ezetimibe require daily dosing, while PCSK9 inhibitors are administered every 2 or 4 weeks. Here, it has to be stressed that poor adherence to statins is associated with significant increases in total mortality, as well as cardiovascular morbidity and mortality. ${ }^{8-11}$

In February 2003, the discovery of PCSK9, a serine protease that binds to and targets the LDL receptors for lysosomal degradation, opened new research avenues
Correspondence: Constantine E Kosmas Tel + I-646-734-7969

Email cekosmas I@gmail.com
Therapeutics and Clinical Risk Management 2020:16 I03|-1037

$103 \mid$

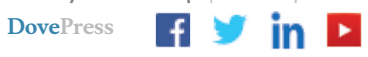

hove:/toiorg/10.21471TCRM.S2305 
into novel therapeutic options to decrease blood levels of LDL-C. ${ }^{12}$ Monoclonal antibodies against PCSK9 have been already approved by the FDA for the treatment of persistent hypercholesterolemia despite maximal therapy with statins. In addition, other lipid-modifying molecules targeting PCSK9, such as small interfering RNA (siRNA) molecules, small molecule inhibitors that disrupt the processing of PCSK9, as well as adnectins, which block the binding of PCSK9 to the LDL receptor, are currently under ongoing investigations. ${ }^{13}$ Inclisiran, a long-acting double-stranded small RNA that halts the transcription of PCSK9, works intracellularly by decreasing the generation of PCSK9 in the hepatocytes, thus leading to an increased number of LDL receptors in the hepatocyte membranes, which results in decreased levels of LDL-C in the blood. ${ }^{14}$

This review aims to present and discuss the current clinical and scientific data pertaining to the role of inclisiran in the treatment of CVD.

\section{Inclisiran: Structure and Function}

Inclisiran is an siRNA molecule, which targets the hepatic production of PCSK9. ${ }^{14}$ siRNAs interfere with the expression of specific genes with complementary nucleotide sequences by selectively and catalytically silencing the translation of their complementary target messenger RNAs (mRNAs) in a sequence-specific manner via intracellular binding to effector RNA-induced silencing complexes. ${ }^{14,15}$

Thus, as it was mentioned earlier, inclisiran, by halting the transcription of PCSK9, increases the numbers of LDL receptors in the hepatocyte membranes, thus resulting in decreased levels of LDL-C in the blood.

This was initially tested in a Phase 1 trial in healthy volunteers with an LDL-C level $\geq 100 \mathrm{mg} / \mathrm{dl}$. In this study, inclisiran was administered subcutaneously in single-dose or multiple-dose regimens. It was shown that doses of $300 \mathrm{mg}$ or more (in single or multiple doses) significantly reduced LDL-C and PCSK9 levels for at least 6 months. In addition, all multiple-dose regimens of inclisiran reduced LDL-C and PCSK9 levels by up to a least-squares mean reduction of $59.7 \%$ and $83.8 \%$, respectively, from baseline to day 84 . There were no serious adverse events observed with inclisiran in this phase 1 trial, the most common adverse events being cough, musculoskeletal pain, nasopharyngitis, headache, back pain, and diarrhea. ${ }^{16}$

\section{Inclisiran in Cardiovascular Disease}

Based on the above, the ORION program was initiated, which is a composite of different worldwide trials, with the purpose of evaluating the efficacy of inclisiran in a variety of subjects, including individuals with high risk for atherosclerotic cardiovascular disease (ASCVD), established ASCVD, as well as patients with familial hypercholesterolemia (FH). The ORION program also focuses on the safety profile of the drug in the short- and long-term period, as well as on its effect on cardiovascular risk.

The ORION-1 Phase 2, multicenter, double-blind, placebo-controlled trial included 501 individuals at high risk for CVD who had elevated LDL-C levels. The mean age of the participants was 63 years, $65 \%$ were men, $69 \%$ had established ASCVD, and 6\% had FH. Overall, $73 \%$ of the participants were receiving statin therapy. The participants were randomized to receive a single dose of placebo or 200,300 , or $500 \mathrm{mg}$ of inclisiran or two doses (at days 1 and 90) of placebo or 100,200 , or $300 \mathrm{mg}$ of inclisiran. The study assessed the percentage change of LDL-C with different doses of inclisiran at 180 days. At day 180, the least-squares mean reductions in LDL-C levels, as compared with placebo, were $27.9 \%$ to $41.9 \%$ after a single dose of inclisiran and $35.5 \%$ to $52.6 \%$ after two doses ( $\mathrm{p}<$ 0.001 for all comparisons vs placebo). The greatest reduction was observed with the two-dose regimen of $300 \mathrm{mg}$ of inclisiran, which decreased LDL-C, PCSK9, and high sensitivity C-reactive protein (hsCRP) by $52.6 \%$ (p $<0.001)$, 69.1\% ( $\mathrm{p}<0.001)$, and 16.7\% ( $<<0.05)$, respectively. ${ }^{14}$ Serious adverse events occurred in $11 \%$ of the patients who received inclisiran and in $8 \%$ of the patients who received placebo. Injection-site reactions occurred in $4 \%$ of patients who received one dose and in $7 \%$ of patients who received two doses of inclisiran. ${ }^{14,15}$ The most common adverse events (occurring in $>2 \%$ of patients) were myalgia, headache, fatigue, nasopharyngitis, back pain, hypertension, diarrhea, and dizziness. The incidences of these adverse events were not significantly different between groups receiving inclisiran and those receiving placebo. ${ }^{15}$ Furthermore, in a study which evaluated the efficacy and safety of inclisiran in the ORION-1 trial by diabetes status, it was shown that inclisiran treatment was associated with marked reductions in mean LDL-C levels from day 14 until day 210 regardless of baseline diabetes status, which indicates that inclisiran may be a viable therapeutic option for lowering LDL-C in the presence and absence of diabetes. Importantly, there were no clinically meaningful changes in glycated hemoglobin (HbA1c) 180 days after treatment initiation, and this persisted over the course of the study. ${ }^{17}$ In conclusion, 
in ORION-1 trial, inclisiran produced significant reductions in LDL-C and PCSK9 levels with a safe side effect profile.

In the one-year follow-up of the ORION-1 trial, it was shown that one dose of inclisiran on day 1 and two doses of inclisiran on days 1 and 90 lowered time-averaged LDL-C levels over 1 year by $29.5 \%$ to $38.7 \%$ and by $29.9 \%$ to $46.4 \%$, respectively, in a dose-dependent manner. A $50 \%$ LDL-C reduction was maintained for at least 6 months after 2 doses of $300 \mathrm{mg}$ of inclisiran on days 1 and 90. In addition, this 2-dose 300-mg regimen of inclisiran produced the greatest mean reduction in LDL-C over 1 year. Incidence of adverse events was similar through to 1 year. Thus, inclisiran emerged as a novel promising therapeutic option for the management of hypercholesterolemia with the convenience of a twice-a-year dosing regimen. $^{18}$

The ORION-3 trial, a phase 2 open-label extension study of the ORION-1 trial, achieved its primary completion in August 2018. At day 210 of ORION-3 trial, LDL-C was reduced by a mean of $51 \%$ and PCSK9 levels were decreased by a mean of $77 \%$. A consistent long-term effect of the $300 \mathrm{mg}$ dose of inclisiran on LDL-C lowering was observed in ORION-3 over approximately 22 months and the time-averaged lowering of LDL-C was approximately $60 \mathrm{mg} / \mathrm{dL}$. During at least 3 years of follow-up, there were no changes in the overall safety profile and no laboratory test abnormalities associated with the treatment, including liver and kidney function tests. ${ }^{19}$ The ORION-3 trial is expected to be completed in 2022 .

The ORION-10 and the ORION-11 were two randomized, double-blind, placebo-controlled, parallel-group, Phase 3 trials. The objectives of the ORION-10 and ORION-11 trials were to assess the efficacy, safety, and adverse-event profile of inclisiran over a period of 18 months. The ORION-10 trial was conducted in the United States and included adults with ASCVD with an LDL-C level $\geq 70 \mathrm{mg} / \mathrm{dl}$. The ORION-11 trial was conducted in Europe and South Africa and included adults with ASCVD with an LDL-C level $\geq 70 \mathrm{mg} / \mathrm{dl}$ or an ASCVD risk equivalent (type 2 diabetes, familial hypercholesterolemia, or a 10-year risk of a cardiovascular event of $\geq 20 \%$ as assessed by the Framingham Risk Score for CVD or equivalent) with an LDL-C level $\geq 100 \mathrm{mg} / \mathrm{dl}$. A total of 1561 and 1617 patients underwent randomization in the ORION-10 and ORION-11 trials, respectively. The use of stable doses of statin therapy was $89.2 \%$ in the ORION-10 trial and 94.7\% in the ORION-11 trial. Patients were randomly assigned to receive either inclisiran (284 mg) or placebo, administered by subcutaneous injection on day 1 , day 90, and every 6 months thereafter over a period of 540 days. The mean LDL-C levels at baseline in ORION-10 and ORION-11 were $104.7 \mathrm{mg} / \mathrm{dl}$ and $105.5 \mathrm{mg} / \mathrm{dl}$, respectively. At day 510, inclisiran reduced LDL-C levels by $52.3 \%$ in the ORION-10 trial and by $49.9 \%$ in the ORION-11 trial with corresponding timeadjusted reductions of $53.8 \%$ and $49.2 \%$, respectively (p $<0.001$ for all comparisons vs placebo). Furthermore, at day 510, inclisiran reduced the levels of PCSK9 by $69.8 \%$ in the ORION-10 trial and by $63.6 \%$ in the ORION-11 trial with corresponding between-group differences (vs placebo) of $83.3 \%$ and $79.3 \%$, respectively $(\mathrm{p}<$ 0.001 for all comparisons vs placebo). In addition, in the ORION-10 trial, inclisiran decreased total cholesterol (TC), apolipoprotein B (ApoB), non-high-density lipoprotein cholesterol (non-HDL-C), triglycerides (TG), and lipoprotein (a) $[\mathrm{Lp}(\mathrm{a})]$ by 33.1\%, 43.1\%, 47.4\%, 12.6\%, and $25.6 \%$, respectively, as compared with placebo, and increased high-density lipoprotein cholesterol (HDL-C) by $5.1 \%$, as compared with placebo. Similarly, in the ORION11 trial, inclisiran decreased TC, ApoB, non-HDL-C, TG, and $\mathrm{Lp}$ (a) by $29.8 \%, 38.9 \%, 43.3 \%, 7.0 \%$, and $18.6 \%$, respectively, as compared with placebo, and increased HDL-C by $6.1 \%$, as compared with placebo. Adverse events were in general similar in the inclisiran and placebo groups in each trial, although injection-site reactions were more frequent with inclisiran than with placebo $(2.6 \%$ vs $0.9 \%$ in the ORION-10 trial and $4.7 \%$ vs $0.5 \%$ in the ORION-11 trial). These reactions were in general mild and not persistent. Importantly, there were no significant changes in the incidence of diabetes mellitus between inclisiran and placebo groups in both trials. ${ }^{20}$

ORION-9 was a double-blind, randomized, placebocontrolled, phase 3 trial, which was conducted to assess the use of inclisiran in a large cohort of adult patients with heterozygous familial hypercholesterolemia ( $\mathrm{HeFH}$ ) who had been treated with a maximally tolerated dose of statin therapy. A total of 482 adults with $\mathrm{HeFH}$ were randomized to receive subcutaneous injections of $300 \mathrm{mg}$ of inclisiran sodium (equivalent to $284 \mathrm{mg}$ of inclisiran) or matching placebo on days 1, 90, 270, and 450. The mean LDL-C level at baseline was $153 \mathrm{mg} / \mathrm{dl}$. At day 510, the mean percent change in the LDL-C level was a reduction of $39.7 \%$ in the inclisiran group versus an increase of $8.2 \%$ in the placebo group, for a between-group difference of -47.9 percentage points $(\mathrm{p}<0.001)$. In addition, at day 510 , the percent 
Table I Summary of Inclisiran Clinical Trials

\begin{tabular}{|c|c|c|c|c|}
\hline Trial & Design & Participants & Intervention & Results \\
\hline $\begin{array}{l}\text { Fitzgerald } \\
\mathrm{K} \text { et } \text { al }^{16}\end{array}$ & $\begin{array}{l}\text { Phase I, } \\
\text { randomized, } \\
\text { single-blind, } \\
\text { placebo- } \\
\text { controlled } \\
\text { study. }\end{array}$ & $\begin{array}{l}\text { Men and women ( } 18 \text { to } 60 \text { years } \\
\text { of age in the single-dose phase and } \\
18 \text { to } 75 \text { years of age in the } \\
\text { multiple-dose phase) who had } \\
\text { a serum LDL-C level of at least } \\
100 \mathrm{mg} / \mathrm{dl} \text { and a fasting triglyceride } \\
\text { level of less than } 400 \mathrm{mg} / \mathrm{dl}(4.5 \\
\mathrm{mmol} / \mathrm{L} \text { ). }\end{array}$ & $\begin{array}{l}\text { Single-ascending-dose phase of } \\
\text { inclisiran or placebo: at a dose of } \\
25,100,300,500 \text {, or } 800 \mathrm{mg} \text {. } \\
\text { Multiple-ascending-dose phase of } \\
\text { inclisiran or placebo: } 125 \mathrm{mg} \\
\text { weekly for four doses, } 250 \mathrm{mg} \\
\text { every other week for two doses, } \\
\text { or } 300 \text { or } 500 \mathrm{mg} \text { monthly for two } \\
\text { doses, with or without concurrent } \\
\text { statin therapy. }\end{array}$ & $\begin{array}{l}\text { Single-dose phase: showed reduction of LDL-C } \\
\text { up to } 50.6 \% \text { from baseline with inclisiran dose of } \\
100 \mathrm{mg} \text { or more. Also, reduction in PCSK } 9 \text { level } \\
\text { up to } 74.5 \% \text { from baseline with inclisiran dose of } \\
300 \mathrm{mg} \text { or more. The reductions were } \\
\text { maintained at day } 180 \text { for doses } 300 \mathrm{mg} \text { or } \\
\text { more. } \\
\text { Multiple-dose phase: showed reduction of LDL- } \\
\mathrm{C} \text { up to } 59.7 \% \text { from baseline to day } 84 \text {. Also, } \\
\text { reduction in PCSK9 level up to } 83.8 \% \text { from } \\
\text { baseline. } \\
\text { No serious adverse events observed with } \\
\text { inclisiran. }\end{array}$ \\
\hline $\begin{array}{l}\text { ORION- } \\
1^{15}\end{array}$ & $\begin{array}{l}\text { Phase 2, } \\
\text { multicenter, } \\
\text { double-blind, } \\
\text { placebo- } \\
\text { controlled } \\
\text { study. }\end{array}$ & $\begin{array}{l}501 \text { men and women, } 18 \text { years of } \\
\text { age or older with } L D L \text { level at } \\
\text { screening higher than } 70 \mathrm{mg} / \mathrm{dl} \\
\text { (for patients with a history of } \\
\text { atherosclerotic cardiovascular } \\
\text { disease) or higher than } 100 \mathrm{mg} / \mathrm{dl} \\
\text { (for patients without a history of } \\
\text { atherosclerotic cardiovascular } \\
\text { disease). }\end{array}$ & $\begin{array}{l}\text { One dose }(200,300, \text { or } 500 \mathrm{mg} \\
\text { on day I) or } 2 \text { doses }(100,200 \text {, or } \\
300 \mathrm{mg} \text { on days I and } 90) \text { of } \\
\text { inclisiran sodium or placebo. }\end{array}$ & $\begin{array}{l}\text { At day } 180 \text {, the mean reductions in LDL-C } \\
\text { levels were } 27.9 \% \text { to } 41.9 \% \text { after a single dose of } \\
\text { inclisiran and } 35.5 \% \text { to } 52.6 \% \text { after two doses } \\
\text { (P<0.00I for all comparisons vs placebo). } \\
\text { The two-dose } 300 \text {-mg inclisiran regimen } \\
\text { produced the greatest reduction in LDL-C } \\
\text { levels: } 48 \% \text { of the patients who received the } \\
\text { regimen had an LDL-C level below } 50 \mathrm{mg} / \mathrm{dl}(1.3 \\
\text { mmol/L) at day } 180 \text {. } \\
\text { At day } 240 \text {, PCSK } 9 \text { and LDL-C levels remained } \\
\text { significantly lower than at baseline in association } \\
\text { with all inclisiran regimens. } \\
\text { Serious adverse events occurred in II\% of the } \\
\text { patients who received inclisiran and in } 8 \% \text { of the } \\
\text { patients who received placebo. }\end{array}$ \\
\hline $\begin{array}{l}\text { ORION-I } \\
\text { I-year } \\
\text { follow- } \\
\text { up }\end{array}$ & $\begin{array}{l}\text { Phase 2, } \\
\text { multicenter, } \\
\text { double-blind, } \\
\text { placebo- } \\
\text { controlled } \\
\text { study. }\end{array}$ & $\begin{array}{l}501 \text { men and women, } 18 \text { years of } \\
\text { age or older with LDL-C level at } \\
\text { screening higher than } 70 \mathrm{mg} / \mathrm{dl} \\
\text { (for patients with a history of } \\
\text { atherosclerotic cardiovascular } \\
\text { disease) or higher than } 100 \mathrm{mg} / \mathrm{dl} \\
\text { (for patients without a history of } \\
\text { atherosclerotic cardiovascular } \\
\text { disease). }\end{array}$ & $\begin{array}{l}\text { One dose }(200,300, \text { or } 500 \mathrm{mg} \\
\text { on day I) or } 2 \text { doses }(100,200 \text {, or } \\
300 \mathrm{mg} \text { on days I and } 90) \text { of } \\
\text { inclisiran sodium or placebo. }\end{array}$ & $\begin{array}{l}\text { One dose of inclisiran on day I and two doses } \\
\text { of inclisiran on days I and } 90 \text { lowered time- } \\
\text { averaged LDL-C levels over I year by } 29.5 \% \text { to } \\
38.7 \% \text { and by } 29.9 \% \text { to } 46.4 \% \text {, respectively, in } \\
\text { a dose-dependent manner. } \\
\text { A } 50 \% \text { LDL-C reduction was maintained for at } \\
\text { least } 6 \text { months after } 2 \text { doses of } 300 \mathrm{mg} \text { of } \\
\text { inclisiran on days I and } 90 \text {, producing the } \\
\text { greatest mean reduction in LDL-C over I year. } \\
\text { Incidence of adverse events was similar through } \\
\text { to I year. }\end{array}$ \\
\hline $\begin{array}{l}\text { ORION- } \\
3^{19}\end{array}$ & $\begin{array}{l}\text { Phase 2, open- } \\
\text { label, long- } \\
\text { term extension } \\
\text { study of the } \\
\text { ORION-I } \\
\text { study. }\end{array}$ & $\begin{array}{l}490 \text { participants who completed } \\
\text { the ORION-I study and were } \\
\text { previously treated with any dose } \\
\text { of inclisiran. }\end{array}$ & $\begin{array}{l}\text { Patients were treated with } 300 \mathrm{mg} \\
\text { inclisiran sodium twice per year ( } \\
=290 \text { ) or } 140 \mathrm{mg} \text { evolocumab } \\
\text { (Repatha, Amgen) every } 2 \text { weeks } \\
\text { for I year followed by } 300 \mathrm{mg} \\
\text { inclisiran sodium on day } 360 \text {, day } \\
450 \text { and every } 6 \text { months after that } \\
(\mathrm{n}=92)\end{array}$ & $\begin{array}{l}\text { At day } 210 \text { of ORION-3 trial, LDL-C was } \\
\text { reduced by a mean of } 5 \mathrm{I} \% \text { and PCSK9 levels } \\
\text { were decreased by a mean of } 77 \% \text {. } \\
\text { A consistent long-term effect of the } 300 \mathrm{mg} \\
\text { dose of inclisiran on LDL-C lowering was } \\
\text { observed in ORION-3 over } \sim 22 \text { months and } \\
\text { the time-averaged lowering of LDL-C was } \\
\sim 60 \mathrm{mg} / \mathrm{dL} \text {. } \\
\text { During at least } 3 \text { years of follow-up, there were } \\
\text { no changes in the overall safety profile and no } \\
\text { laboratory test abnormalities associated with } \\
\text { the treatment. }\end{array}$ \\
\hline
\end{tabular}

(Continued) 
Table I (Continued).

\begin{tabular}{|c|c|c|c|c|}
\hline Trial & Design & Participants & Intervention & Results \\
\hline $\begin{array}{l}\text { ORION- } \\
10^{20}\end{array}$ & $\begin{array}{l}\text { Phase 3, } \\
\text { randomized, } \\
\text { double-blind, } \\
\text { placebo- } \\
\text { controlled, } \\
\text { parallel group } \\
\text { study. }\end{array}$ & $\begin{array}{l}\text { I56I adults in the United States } \\
\text { with atherosclerotic } \\
\text { cardiovascular disease and LDL-C } \\
\text { levels at screening } 70 \mathrm{mg} / \mathrm{dL} \text { or } \\
\text { higher. }\end{array}$ & $\begin{array}{l}\text { Patients were randomly assigned } \\
\text { in a I:I ratio to receive either } \\
\text { inclisiran }(284 \mathrm{mg}) \text { or placebo, } \\
\text { administered by subcutaneous } \\
\text { injection on day I, day } 90 \text {, and } \\
\text { every } 6 \text { months thereafter over } \\
\text { a period of } 540 \text { days. }\end{array}$ & $\begin{array}{l}\text { At day } 510 \text {, inclisiran reduced } L D L-C \text { levels by } \\
52.3 \% \text { with corresponding time-adjusted } \\
\text { reductions of } 53.8 \% \text { ( } P<0.00 \mathrm{I} \text { for all } \\
\text { comparisons vs placebo). } \\
\text { Adverse events were generally similar in the } \\
\text { inclisiran and placebo groups, although } \\
\text { injection-site adverse events were more } \\
\text { frequent with inclisiran than with placebo } \\
(2.6 \% \text { vs } 0.9 \%) \text {. }\end{array}$ \\
\hline $\begin{array}{l}\text { ORION- } \\
11^{20}\end{array}$ & $\begin{array}{l}\text { Phase 3, } \\
\text { randomized, } \\
\text { double-blind, } \\
\text { placebo- } \\
\text { controlled, } \\
\text { parallel group } \\
\text { study. }\end{array}$ & $\begin{array}{l}1617 \text { adults in Europe and South } \\
\text { Africa with atherosclerotic } \\
\text { cardiovascular disease or an } \\
\text { atherosclerotic cardiovascular } \\
\text { disease risk equivalent and LDL-C } \\
\text { levels at screening } 70 \mathrm{mg} / \mathrm{dl} \text { and } \\
100 \mathrm{mg} / \mathrm{dL} \text { or higher, respectively. }\end{array}$ & $\begin{array}{l}\text { Patients were randomly assigned } \\
\text { in a } 1: I \text { ratio to receive either } \\
\text { inclisiran ( } 284 \mathrm{mg} \text { ) or placebo, } \\
\text { administered by subcutaneous } \\
\text { injection on day I, day } 90 \text {, and } \\
\text { every } 6 \text { months thereafter over } \\
\text { a period of } 540 \text { days. }\end{array}$ & $\begin{array}{l}\text { At day } 510 \text {, inclisiran reduced } L D L \text { cholesterol } \\
\text { levels by } 49.9 \% \text { with corresponding time- } \\
\text { adjusted reductions of } 49.2 \% \text { ( } P<0.00 \text { I for all } \\
\text { comparisons vs placebo). } \\
\text { Adverse events were generally similar in the } \\
\text { inclisiran and placebo groups, although } \\
\text { injection-site adverse events were more } \\
\text { frequent with inclisiran than with placebo }(4.7 \% \\
\text { vs } 0.5 \%) \text {. }\end{array}$ \\
\hline $\begin{array}{l}\text { ORION- } \\
9^{21}\end{array}$ & $\begin{array}{l}\text { Phase 3, } \\
\text { double-blind, } \\
\text { randomized, } \\
\text { placebo- } \\
\text { controlled } \\
\text { study. }\end{array}$ & $\begin{array}{l}482 \text { adults with diagnosis of } \\
\text { heterozygous familial } \\
\text { hypercholesterolemia with LDL of } \\
\text { at least } 100 \mathrm{mg} / \mathrm{dL} \text {, despite } \\
\text { receiving a maximally accepted } \\
\text { dose of statin therapy with or } \\
\text { without ezetimibe. }\end{array}$ & $\begin{array}{l}\text { The patients were assigned in } \\
\text { a I:I ratio to receive inclisiran } \\
\text { sodium (at a dose of } 300 \mathrm{mg} \text { ) or } \\
\text { matching placebo, which were } \\
\text { both administered as a } 1.5-\mathrm{mL} \\
\text { subcutaneous injection on days I, } \\
90,270 \text {, and } 450 \text {. }\end{array}$ & $\begin{array}{l}\text { At day } 510 \text {, the percent change in the LDL-C } \\
\text { level was a reduction of } 39.7 \% \text { in the inclisiran } \\
\text { group and an increase of } 8.2 \% \text { in the placebo } \\
\text { group, for a between-group difference of } \\
-47.9 \text { percentage points. } \\
\text { Adverse events and serious adverse events } \\
\text { were similar in the two groups. }\end{array}$ \\
\hline $\begin{array}{l}\text { ORION- } \\
5^{22} \\
\text { (Ongoing) }\end{array}$ & $\begin{array}{l}\text { Phase 3, } \\
\text { double-blind, } \\
\text { placebo- } \\
\text { controlled, } \\
\text { open-label, } \\
\text { multicenter } \\
\text { study. }\end{array}$ & $\begin{array}{l}45 \text { adults with diagnosis of } \\
\text { homozygous familial } \\
\text { hypercholesterolemia with LDL of } \\
\text { at least } 100 \mathrm{mg} / \mathrm{dL} \text {, despite } \\
\text { receiving a maximally accepted } \\
\text { dose of statin therapy with or } \\
\text { without ezetimibe. }\end{array}$ & $\begin{array}{l}\text { Part one: patients will receive two } \\
300-\mathrm{mg} \text { doses of inclisiran sodium } \\
\text { or placebo at day one and day } 90 \\
\text { (three months). } \\
\text { Part two: patients will receive } \\
\text { a } 300-\mathrm{mg} \text { dose of inclisiran sodium } \\
\text { on day } 270 \text { (nine months), day } 450 \\
\text { ( } 15 \text { months) and day } 630 \text { ( } 21 \\
\text { months). }\end{array}$ & $\begin{array}{l}\text { Estimated study completion date: } \\
\text { September } 2021 \text {. }\end{array}$ \\
\hline $\begin{array}{l}\text { ORION- } \\
4^{24} \\
\text { (Ongoing) }\end{array}$ & $\begin{array}{l}\text { Phase 3, } \\
\text { double-blind, } \\
\text { randomized, } \\
\text { placebo- } \\
\text { controlled } \\
\text { study. }\end{array}$ & $\begin{array}{l}15,000 \text { participants aged } 55 \text { years } \\
\text { or older with pre-existing ASCVD. }\end{array}$ & $\begin{array}{l}\text { Patients will receive inclisiran } \\
300 \mathrm{mg} \text { or placebo on the day of } \\
\text { randomization, at } 3 \text { months and } \\
\text { then every } 6 \text { months. }\end{array}$ & $\begin{array}{l}\text { Estimated primary completion date: } \\
\text { December } 2024 . \\
\text { Estimated study completion date: } \\
\text { December } 2049 .\end{array}$ \\
\hline
\end{tabular}

change in the PCSK9 level was a reduction of $60.7 \%$ in the inclisiran group versus an increase of $17.7 \%$ in the placebo group, for a between-group difference of -78.4 percentage points $(\mathrm{p}<0.001)$. The time-averaged percent change in the LDL-C level between day 90 and day 540 was a reduction of $38.1 \%$ in the inclisiran group versus an increase of $6.2 \%$ in the placebo group, for a between-group difference of
-44.3 percentage points $(\mathrm{p}<0.001)$. There were marked reductions in LDL-C levels in all genotypes of FH. The incidence of adverse events and serious adverse events was similar between the two groups. ${ }^{21}$

On the other hand, ORION-5 is an ongoing phase 3, double-blind, placebo-controlled, open-label, multicenter study [ClinicalTrials.gov Identifier: NCT03851705], which 
will evaluate the safety, tolerability, and efficacy of inclisiran in subjects with homozygous familial hypercholesterolemia $(\mathrm{HoFH}){ }^{22}$

In a meta-analysis, which assessed data from 3 randomized clinical trials comprising 3,660 patients, it was shown that inclisiran, as compared with placebo, decreased LDL-C levels by 51\% ( $p<0.001)$. It also significantly decreased TC by $37 \%$, ApoB by $41 \%$, and non-HDL-C by $45 \%$ (all $\mathrm{p}<0.001$ ). Most importantly, in this meta-analysis, inclisiran was also associated with a $24 \%$ lower major adverse cardiovascular events rate. No differences were found in adverse events, abnormalities in liver function tests, or creatine kinase levels between the inclisiran and placebo groups. However, mild injection site reactions occurred more frequently in the inclisiran group. ${ }^{23}$

Based on the current available data, as described above, inclisiran appears to have a consistent long-term effect on LDL-C lowering and a favorable side effect profile. However, further long-term outcome trials are required to definitely establish the beneficial role of inclisiran in the reduction of cardiovascular risk.

To that effect, ORION-4 is an ongoing double-blind, randomized, placebo-controlled, phase 3 trial [ClinicalTrials.gov Identifier: NCT03705234], which will assess the effects of inclisiran on clinical outcomes among patients with ASCVD. The study started in October 2018 and its primary completion date is estimated to be in December 2024. The study is intended to be conducted at approximately 180 clinical sites in the UK and the USA. Approximately 15,000 participants aged 55 years or older with pre-existing ASCVD will be randomized between inclisiran sodium $300 \mathrm{mg}$ and matching placebo (given by subcutaneous injection on the day of randomization, at 3 months and then every 6 months) in a 1:1 ratio for a planned median follow-up duration of about 5 years. The primary outcome of ORION-4 is defined as time to first occurrence of coronary heart disease (CHD) death, myocardial infarction (MI), fatal or non-fatal ischemic stroke, or urgent coronary revascularization procedure. The secondary outcomes include the number of participants with a composite of $\mathrm{CHD}$ death or $\mathrm{MI}$ and the number of participants with cardiovascular death. ${ }^{24}$ The results of the ORION-4 trial will provide valuable information regarding the benefit of inclisiran in reducing major adverse cardiovascular events and improving outcomes in patients with ASCVD.
A summary of the above-mentioned clinical trials with inclisiran is shown in Table 1.

\section{Conclusions and Future Directions}

In conclusion, inclisiran has thus far demonstrated to provide significant long-term reductions in the levels of LDL-C in blood associated with notable decreases in PCSK9 levels. Furthermore, inclisiran appears to have a generally favorable side effect profile. The convenience of a twice-a-year dosing regimen offers an advantage against medication noncompliance, which is one of the main causes for not achieving LDL-C goals with standard therapy. Thus, inclisiran has emerged as a novel promising therapeutic option for the management of hypercholesterolemia. As it was mentioned above, the results of the ORION-4 trial are expected to shed more light regarding the effect of inclisiran in the reduction of major adverse cardiovascular events and the improvement of outcomes in patients with ASCVD.

\section{Disclosure}

Dr. Kosmas and Dr. Guzman have served on the Dyslipidemia Speaker Bureau of Amgen, Inc. Constantine E Kosmas and Eliscer Guzman report personal fees from Amgen, outside the submitted work. The authors report no other conflicts of interest in this work.

\section{References}

1. GBD 2017 Causes of Death Collaborators. Global, Regional, and National Age-Sex-Specific Mortality for 282 Causes of Death in 195 Countries and Territories, 1980-2017: A Systematic Analysis for the Global Burden of Disease Study 2017. Lancet. 2018;392 (10159):1736-1788.

2. Cholesterol Treatment Trialists' (CTT) Collaboration, Baigent C, Blackwell L, et al. Efficacy and safety of more intensive lowering of LDL cholesterol: a meta-analysis of data from 170,000 participants in 26 randomised trials. Lancet. 2010;376(9753):1670-1681.

3. Grundy SM, Stone NJ, Bailey AL, et al. 2018 AHA/ACC/AACVPR/ AAPA/ABC/ACPM/ADA/AGS/APhA/ASPC/NLA/PCNA Guideline on the Management of Blood Cholesterol: A Report of the American College of Cardiology/American Heart Association Task Force on Clinical Practice Guidelines. J Am Coll Cardiol. 2019;73(24):e285.

4. Mach F, Baigent C, Catapano AL, et al. ESC Scientific Document Group. 2019 ESC/EAS Guidelines for the management of dyslipidaemias: lipid modification to reduce cardiovascular risk. Eur Heart $J$. 2020;41(1):111-188.

5. Rizzo M, Banach M, Montalto G, Mikhailidis DP. Lipid-lowering therapies and achievement of LDL-cholesterol targets. Arch Med Sci. 2012;8(4):598-600.

6. Bates TR, Connaughton VM, Watts GF. Non-adherence to statin therapy: a major challenge for preventive cardiology. Expert Opin Pharmacother. 2009;10(18):2973-2985.

7. Wong ND, Chuang J, Wong K, Pham A, Neff D, Marrett E. Residual dyslipidemia among United States adults treated with lipid modifying therapy (data from National Health and Nutrition Examination Survey 2009-2010). Am J Cardiol. 2013;112(3):373-379. 
8. Lardizabal JA, Deedwania PC. Benefits of statin therapy and compliance in high risk cardiovascular patients. Vasc Health Risk Manag. 2010;6:843-853.

9. Ford I, Murray H, Packard CJ, Shepherd J, Macfarlane PW, Cobbe SM. West of Scotland Coronary Prevention Study Group. Long-term follow-up of the West of Scotland Coronary Prevention Study. N Engl J Med. 2007;357(15):1477-1486.

10. Ho PM, Magid DJ, Shetterly SM, et al. Medication nonadherence is associated with a broad range of adverse outcomes in patients with coronary artery disease. Am Heart J. 2008;155(4):772-779.

11. Kosmas CE, Silverio D, Ovalle J, Montan PD, Guzman E. Patient adherence, compliance, and perspectives on evolocumab for the management of resistant hypercholesterolemia. Patient Prefer Adherence. 2018;12:2263-2266.

12. Seidah NG, Benjannet S, Wickham L, et al. The secretory proprotein convertase neural apoptosis-regulated convertase 1 (NARC-1): liver regeneration and neuronal differentiation. Proc Natl Acad Sci US A. 2003;100(3):928-933.

13. Kosmas CE, DeJesus E, Morcelo R, Garcia F, Montan PD, Guzman E. Lipid-lowering interventions targeting proprotein convertase subtilisin/kexin type 9 (PCSK9): an emerging chapter in lipid-lowering therapy. Drugs Context. 2017;6:212511.

14. Kosmas CE, Muñoz Estrella A, Sourlas A, et al. Inclisiran: a new promising agent in the management of hypercholesterolemia. Diseases. 2018;6(3):63.

15. Ray KK, Landmesser U, Leiter LA, et al. Inclisiran in patients at high cardiovascular risk with elevated LDL cholesterol. $N$ Engl J Med. 2017;376(15):1430-1440.

16. Fitzgerald K, White S, Borodovsky A, et al. A highly durable RNAi therapeutic inhibitor of PCSK9. N Engl J Med. 2017;376(1):41-51.
17. Leiter LA, Teoh H, Kallend D, et al. Inclisiran Lowers LDL-C and PCSK9 irrespective of diabetes status: the ORION-1 randomized clinical trial. Diabetes Care. 2019;42(1):173-176.

18. Ray KK, Stoekenbroek RM, Kallend D, et al. Effect of 1 or 2 doses of inclisiran on low-density lipoprotein cholesterol levels: one-year follow-up of the ORION-1 randomized clinical trial. JAMA Cardiol. 2019;4(11):1067-1075.

19. Kastelein JJ, et al. Late Breakers. Long-term inclisiran in subjects with high CV risk and elevated LDL-C. Presented at: National Lipid Association Scientific Sessions; May 16-19, 2019; Miami.

20. Ray KK, Wright RS, Kallend D, et al. ORION-10 and ORION-11 Investigators. Two Phase 3 Trials of inclisiran in patients with elevated LDL cholesterol. N Engl J Med. 2020;382(16):1507-1519.

21. Raal FJ, Kallend D, Ray KK, et al. ORION-9 Investigators. Inclisiran for the treatment of heterozygous familial hypercholesterolemia. $N$ Engl J Med. 2020;382(16):1520-1530.

22. A Study of Inclisiran in Participants With Homozygous Familial Hypercholesterolemia (HoFH) (ORION-5). ClinicalTrials.gov Identifier: NCT03851705. Available from: http:/clinicaltrials.gov/ ct2/show/NCT03851705. Accessed August 22, 2020.

23. Khan SA, Naz A, Qamar Masood M, Shah R. Meta-analysis of inclisiran for the treatment of hypercholesterolemia. Am J Cardiol. 2020;:S0002-9149(20):30866.

24. A Randomized Trial Assessing the Effects of Inclisiran on Clinical Outcomes Among People With Cardiovascular Disease (ORION-4). ClinicalTrials.gov Identifier: NCT03705234. Available from: http:// clinicaltrials.gov/ct2/show/NCT03705234. Accessed August 22, 2020.
Therapeutics and Clinical Risk Management

\section{Publish your work in this journal}

Therapeutics and Clinical Risk Management is an international, peerreviewed journal of clinical therapeutics and risk management, focusing on concise rapid reporting of clinical studies in all therapeutic areas, outcomes, safety, and programs for the effective, safe, and sustained use of medicines. This journal is indexed on PubMed Central, CAS,

\section{Dovepress}

EMBase, Scopus and the Elsevier Bibliographic databases. The manuscript management system is completely online and includes a very quick and fair peer-review system, which is all easy to use. Visit http://www.dovepress.com/testimonials.php to read real quotes from published authors. 